\title{
Intercity Transport
}




\title{
Intercity Transport
}

Engineering and Planning

\author{
TOM RALLIS
}

Technical University of Denmark, Copenhagen

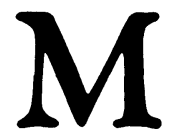


(C) Tom Rallis, 1977

Softcover reprint of the hardcover 1st edition 1977 978-0-333-19563-5

All rights reserved. No part of this publication may be reproduced or transmitted, in any form or by any means, without permission.

First published 1977 by

THE MACMILLAN PRESS LTD

London and Basingstoke

Associated companies in New York Dublin

Melbourne Johannesburg and Madras

ISBN 978-1-349-02925-9 ISBN 978-1-349-02923-5 (eBook)

DOI 10.1007/978-1-349-02923-5

This book is sold subject to the standard conditions of the Net Book Agreement 


\section{Contents}

$\begin{array}{ll}\text { Preface } & \text { ix }\end{array}$

Introduction $\quad$ xi

1 Transport Evolution 1

1.1 Transport before $1500 \quad 1$

1.2 Transport after 1500

1.2.1 Land transport

$\begin{array}{ll}\text { 1.2.2 Sea and air transport } & 12\end{array}$

1.3 Transport systems 25

1.3.1 The intercontinental network 25

1.3.2 European network 28

1.3.3 The American network $\quad 36$

1.3.4 The Tokaido corridor in Japan $\quad 40$

1.4 General observations 41

References $\quad 42$

2 ENVIRONMENTAL Factors IN INTERCITY TRANSPORT 43

2.1 Accidents 43

2.1.1 Safety at sea $\quad 44$

2.1.2 Safety on railways 48

2.1.3 Safety on roads $\quad 52$

2.1.4 Air safety 55

2.2 Noise $\quad 69$

2.2.1 Railway traffic noise and sea traffic noise $\quad 69$

2.2.2 Road traffic noise $\quad 71$

2.2.3 Air traffic noise $\quad 73$

2.3 Air pollution $\quad 80$

References $\quad 84$ 
3 INTERCITY TRANSPORT CAPACITY 86

$\begin{array}{ll}3.1 \text { Sea transport } & 87\end{array}$

$\begin{array}{ll}3.1 .1 \text { Seaways } & 87\end{array}$

$\begin{array}{ll}3.1 .2 \text { Ports } & 88\end{array}$

$\begin{array}{ll}3.2 \text { Rail transport } & 95\end{array}$

3.2.1 Through tracks $\quad 95$

$\begin{array}{ll}\text { 3.2.2 Passenger handling stations } & 96\end{array}$

$\begin{array}{ll}3.2 .3 \text { Goods handling stations } & 97\end{array}$

3.3 Road transport $\quad 99$

3.3.1 Highways, motorways $\quad 99$

$\begin{array}{ll}\text { 3.3.2 Bus stations } & 101\end{array}$

$\begin{array}{ll}3.3 .3 \text { Road haulage centres } & 101\end{array}$

$\begin{array}{ll}3.3 .4 \text { Parking areas } & 101\end{array}$

$\begin{array}{ll}3.3 .5 \text { Toll booths } & 101\end{array}$

3.4 Air transport $\quad 102$

$\begin{array}{ll}3.4 .1 \text { Airways and runways } & 102\end{array}$

3.4.2 Air-ground communications $\quad 103$

$\begin{array}{ll}\text { 3.4.3 Apron } & 112\end{array}$

$\begin{array}{ll}3.5 \text { Passenger and freight transport } & 114\end{array}$

$\begin{array}{ll}3.5 .1 \text { Passenger and freight capacity } & 115\end{array}$

$\begin{array}{ll}3.5 .2 \text { Transport mileage capacity } & 121\end{array}$

References 122

4 Transport Economy, Policy and Location 124

$\begin{array}{ll}4.1 \text { Economy and transport } & 124\end{array}$

$\begin{array}{ll}4.2 \text { Costs and investments } & 125\end{array}$

4.2.1 Capital costs 125

$\begin{array}{ll}\text { 4.2.2 Fuel costs } & 127\end{array}$

4.2.3 Sea transport $\quad 130$

4.2.4 Rail transport 134

4.2.5 Road transport $\quad 136$

$\begin{array}{ll}\text { 4.2.6 Air transport } & 138\end{array}$

4.2.7 Indirect costs of transport systems $\quad 139$

4.3 Prices, fares and charges 142

$\begin{array}{ll}\text { 4.3.1 Ship's charges } & 144\end{array}$

$\begin{array}{ll}\text { 4.3.2 Railway charges } & 144\end{array}$

4.3.3 Road charges versus rail charges 145

4.3.4 Investment in infrastructure; subsidies and discrimination 146

$\begin{array}{ll}\text { 4.3.5 Taxation } & 147\end{array}$ 
4.3.6 Transport costs in industry

4.3.7 Passenger transport fares

4.3.8 Budgets

4.4 Location theory and transport networks 152

4.5 Scheduling and location $\quad 166$

References 171

5 Transport Demand and Planning 174

5.1 Forecasting growth curves $\quad 174$

5.1.1 Arithmetical forecast (extrapolation) 174

5.1.2 Geometrical forecast (exponential extrapolation) $\quad 174$

5.1.3 Logistic forecast (gradually declining increase) 175

5.2 Forecasting growth formulae for passenger traffic 177

5.2.1 Estimation of passenger traffic volume between cities $\quad 177$

$\begin{array}{ll}\text { 5.2.2 Distribution of traffic between modes } & 178\end{array}$

$\begin{array}{ll}5.2 .3 \text { Network flow } & 178\end{array}$

5.3 Forecasting models for passenger transport 179

$\begin{array}{lr}\text { 5.3.1 Sequential models } & 179\end{array}$

5.3.2 Transport system models $\quad 180$

5.4 Estimation of freight traffic volumes between cities 183

$\begin{array}{lr}\text { 5.4.1 The inventory model } & 185\end{array}$

$\begin{array}{ll}\text { 5.4.2 The behavioural model } & 187\end{array}$

$\begin{array}{ll}5.5 \text { Evaluation procedures } & 187\end{array}$

5.5.1 Transport systems and cost-benefit analysis 187

$\begin{array}{ll}\text { 5.6 Some transport plans } & 189\end{array}$

5.6.1 Reshaping British Rail 189

5.6.2 The Channel tunnel 190

5.6.3 British air and sea links 195

5.6.4 Intercity transport in Europe 1970-2000 201

5.6.5 Transport in the north-east corridor of the United States 214

References 224

$\begin{array}{ll}\text { Glossary of terms } & 226\end{array}$

$\begin{array}{ll}\text { Index } & 229\end{array}$ 


\section{Preface}

This book is for students in civil engineering who want to know something about intercity transport: its environmental, capacity and economic factors and its modes-shipping, railways, public road transport; air transport and pipelines. It describes the evolution of transport and transport systems, and discusses forecasting and evaluation. I also hope that, because it contains a considerable amount of background material, it will also be of interest to planners, designers, managers and consultants.

The book is a guide for an advanced course in transport. Students using it will have taken basic courses in road, railway and airport construction, road traffic engineering, urban traffic engineering and planning, advanced regional science, port construction, statistics and operational research, transport economy and investment analysis. Therefore brevity is both useful and necessary.

Many statistical data and examples are presented which should be useful in discussions and problem solving. Not all the data are from the most recent years, but this helps emphasise the changing values of intercity transport. I have been careful not to put too many Danish transport problems into the book; even so our problems at Great Belt and in Saltholm are very much like the problems of the Channel tunnel and the third London Airport. Even though these latter problems are postponed indefinitely, it is interesting to consider the evaluations. One day such problems will be solved. Perhaps air traffic has been somewhat overemphasised; however, according to my experience this is necessary because students know too little about this relatively new means of transport.

In recent years many transport problems have been treated in the literature, but to my knowledge, a book has not been published which offers a general, comparative description of transport, and which is applicable in practice to all service sectors of our transport networks.

Transport engineering is the science of measuring transport, the formulation of basic laws in relation to transport, and the application of this knowledge to the professional practice of planning, designing and operating transport systems.

I am indebted to the Technical University of Denmark and to the Directorate of Civil Aviation in Denmark for assistance, making it possible 
for me to visit the University of California, Berkeley, in 1962 and 1970, the New York Port Authority, the Federal Aviation Agency in Washington and General Motors in Detroit in 1965, and finally the South-east India Railways in Calcutta and the Tokaido Line in Tokyo in 1967. Without these connections, as well as those in Europe, including C.E.M.T. and O.E.C.D. in Paris and the University of Southampton, England, this book would never have been written.

Abbreviations, symbols, nomenclature and units have been used as consistently as possible, bearing in mind the variety of sources but any exceptions that may be found are entirely my responsibility. I should also like to draw attention to the comprehensive list of references included at the end of each chapter. Last but not least I wish to thank my former students O. Buskgaard, L. Denver, P. Bjorn Andersen and C. Wass for all their inspiration and help.

Technical University of Denmark

Tom Rallis

Copenhagen, 1977 


\section{Introduction}

\section{Elements and Problems in Transport}

Life is movement. In civilised life this movement is transport, providing connections between individuals and communities. Transport, the movement of persons and freight from one place to another, dictates the rise and fall of cultures.

The main elements in transport are the network, the means of transport and the people. The main problems in transport are the environment, the capacity and the economy.

\section{Transport and History}

Some main elements of transport, such as road transport and sea transport, have been in use for several thousand years; others, such as the railways and air transport, have only occurred recently, in the nineteenth and twentieth centuries.

The people remain basically the same; the existing networks have been improved, both roads and harbours, and new networks, such as railways, and terminals, such as airports, have been established. However, the means of transport have improved markedly, the horsedrawn carriage and the sailing ship have been replaced by the automobile and the steamship, and new means of transport, such as locomotives and aircraft have been invented to increase speed. Some means, such as ships, railways and buses, trucks, pipelines and aircraft, are used mainly for long distance traffic and for public transport. These means of transport have, in the context of the main transport problems, the added features of better safety, capacity and economy compared with the individual short distance means of transport, such as the passenger motor vehicle.

\section{Methods in Transport Engineering}

To describe transport, three methods can be used: to give facts, to set up common laws for the comparison of facts, and to create facts in the form of planning, construction and simulation of transport systems. Normally the second method of comparing facts by the use of laws is the scientific method chosen. The laws of statistics and the theory of probability are used both for the solution of safety and queueing problems and for solving economic problems. 
xii

\section{Aims in Transport Engineering}

It is the goal of the transport engineer to reduce environmental disturbance caused by transportation, that is to reduce the number of people killed by accidents, disturbed by noise and air pollution, etc., to improve the layout, service and handling of passengers and freight, to locate and forecast the traffic distributed into regions, transport modes and transport networks and finally to use these facts to plan and construct better transport systems taking into consideration both constructional and operational costs. The planning also contains political, military, and sociological aims well as aesthetics, which are difficult to describe in technical-economic models. Often the transport engineer has to base his decisions on inexact models, and accommodate political motives. 